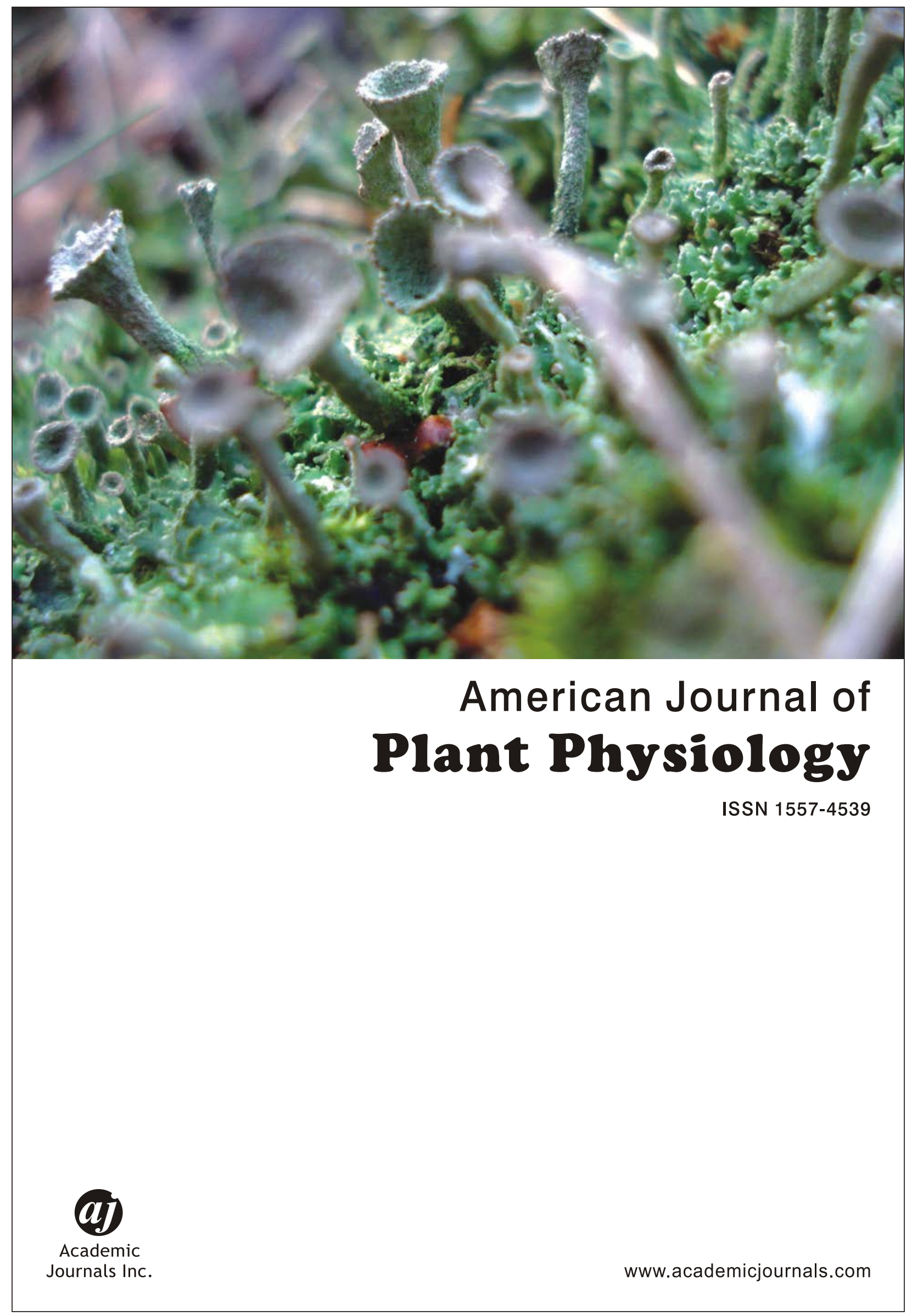




\title{
Competitive Effect of Prominent Weeds on Cowpea Cultivar in a Typical Ultisol
}

\author{
${ }^{1,2}$ Edokpolor Osazee Ohanmu and ${ }^{2}$ Beckley Ikhajiagbe \\ ${ }^{1}$ Department of Plant Biology and Biotechnology, Faculty of Science, Edo University lyamho, Edo State, Nigeria \\ ${ }^{2}$ Environmental Biotechnology and Sustainability Research Group, Department of Plant Biology and Biotechnology, University of Benin, \\ Nigeria
}

\section{Abstract}

Background and Objective: Weeds reduced cowpea yield and quality by competing for light, water and nutrients. Hence identifying a cowpea cultivar that completes well against weeds will go a long way in increasing food sustain ability and security. Therefore, this study investigated the competition between cowpea (TVU-180) and selected weeds prominent in a typical ultisol.

Materials and Methods: The study involved 10 treatments and a control. Each treatment included three seeds of the cowpea sowed alongside the selected weeds, Chrysopogon aciculatus (WA), Eleusine indica (WB), Cynodon dactylon (WC), Axonopus compressus (WD), Panicumn maximum (WE), Setaria bartata (WF), Sporobolus pyramidalis (WG), Commelina benghalensis (WH), Paspalum vaginatum (WI), a combination of the weeds (WJ) and the control arranged in a randomized block design (RBD) and replicated thrice. Results: The result of the study showed that there were significant weed competitive effect on the cowpea parameters examined. The plant height and number of leaflet of cowpea in WE, WA and WJ treatments were significantly increased over the control. Noyield parameters were recorded in the associated weed treatments except in WA, WI and the control. However, weed competitiveness significantly reduced the bean yield of the cowpea in the WI and WA treatments. Weed competitiveness resulted in the lowest plant dry weight of the TVu-180 in WB when compared with control. There was variation in the light harvesting pigments with WH, WI and WB having a higher chlorophyll-a/b, carotenoid and lycopene content than the control. The WA and the control had the highest soil total $\mathrm{N}$, $\mathrm{P}$ and $\mathrm{K}$ content. Conclusion: The cowpea TVu-180 variety was more promising for cultivation in a farm infested with Chrysopogon aciculatus and Paspalum vaginatum weeds without significant effects in the yield and quality of the plant.

Key words: Weeds, cowpea TVu-180 variety, chrysopogon aciculat, paspalum vaginatum, chlorophyll content

Citation: Edokpolor Osazee Ohanmu and Beckley Ikhajiagbe, 2019. Competitive effect of prominent weeds on cowpea cultivar in a typical ultisol. Am. J. Plant Physiol., 14: 1-8.

Corresponding Author: Edokpolor Osazee Ohanmu, Department of Plant Biology and Biotechnology, Faculty of Science, Edo University, lyamho, Edo State, Nigeria, Tel: +2347084059346

Copyright: @ 2019 Edokpolor Osazee Ohanmu and Beckley Ikhajiagbe. This is an open access article distributed under the terms of the creative commons attribution License, which permits unrestricted use, distribution and reproduction in any medium, provided the original author and source are credited.

Competing Interest: The authors have declared that no competing interest exists.

Data Availability: All relevant data are within the paper and its supporting information files. 


\section{INTRODUCTION}

Cowpea (Vigna unguiculata L. Walp) is an importance and major staple crop to millions of people in the tropics. Cowpea is a dicotyledoneae, belonging to the order Fabales, family Fabaceae, sub-family Faboideae, tribe Phaseoleae, sub-tribe Phasiolenae and genus Vigna ${ }^{1,2}$. They are an important component among the various farming system because of their ability to fix atmospheric nitrogen through a symbiotic relationship with a specific soil bacterium, the rhizobium. Cowpea constitutes a valuable source of protein as well as rich amino acid profile ${ }^{3}$ and is one of the widely cultivated leguminous crops in the savannah region of west Africa ${ }^{4}$. The world estimated annual cowpea production is around $4.5 \mathrm{~m} \mathrm{t}$ from an estimated land area $^{5}$ of $12.6 \mathrm{~m}$ ha. West Africa accounts for about $80 \%$ of the estimated total land area under cowpea cultivation ${ }^{6}$.

In west Africa, the cowpea-producing countries are Nigeria, Niger, Mali, Senegal, Burkina Faso and Ghana, with its origin traced to Nigeria. Nigeria is the largest producer and consumer of cowpea worldwide with an annual production of $2.4 \mathrm{~m}$ t on about 5 million ha area ${ }^{6}$. Cowpea can be grown over a wide range of soil type and serves as food, animal feed, cash and manure. However, with the great economic potential of cowpea as both domestic and commercial crop, a number of constraints limits its production. These constraints includes, drought and weeds ${ }^{7-10}$, insect pests and diseases ${ }^{11,12}$, heavy metal pollution ${ }^{13}$, inadequate knowledge of good cultural practices and high yielding varieties resulting in poor yield ${ }^{14}$.

Although the magnitude of yield depend on the crop variety, weed density and management practices, weeds constitute a major constraint to crop production worldwide. Yield losses caused by weeds alone in cowpea production can range from $25-76 \%$ depending on the cultivar and environment ${ }^{7,10,15,16}$. Most of the problems caused by weed competition in cowpea production ranges from reduction in crop yield, less efficient land use, higher cost of production due to insects and plant disease control, reduction in crop quality, water management problems and less efficient utilization of labour ${ }^{17-19}$. Growing cowpea in Nigeria have not been without some prevailing challenges as different researches in compacting weeds have been examined, however weeds continue to render havoc to the efforts geared towards increasing crop productivity.

Therefore, comparatively identifying a preferred cowpea variety that can withstand an array of weeds will go a long way in increasing crop yield. Thus the study aimed to determine the effects of different prominent weed on the growth productivity and yield of cowpea (TVu-180) variety in an ultisol.

\section{MATERIALS AND METHODS}

Experimental design: This study was conducted on September 5th, 2016 in the Botanic garden of the Department of Plant Biology and Biotechnology, University of Benin, Benin city, Nigeria. The cowpea (TVu-180) variety was procured from the International Institute of Tropical Agriculture (IITA), Ibadan, Nigeria (Plate 1). The different weeds used for the experiment were obtained from within the school campus and Santua Garden, Ugbowo, Nigeria. Nine weed species namely, Chrysopogon aciculatus, Eleusine indica, Cynodon dactylon, Axonopus compressus, Panicumn maximum, Setaria bartata, Sporobolus pyramidalis, Commelina benghalensis and Paspalum vaginatum were propagated separately and holistically alongside the cowpea variety. About $20 \mathrm{~kg}$ of the top soil obtained from the botanic garden was sent to the laboratory for physicochemical analysis. The soils were adequately moistened and measured into the different bowls. Thereafter, the different weeds were planted and left to adapt for 2 weeks before planting the cowpea seeds. Three seeds were sown in each bowl. The plants were watered regularly thrice a week. Manual hand weeding method was used in removing unwanted weeds. This was done at various periods of 2, 4, 6 and 8 weeks after planting (WAP) to ensure that only the weed species that were required for the

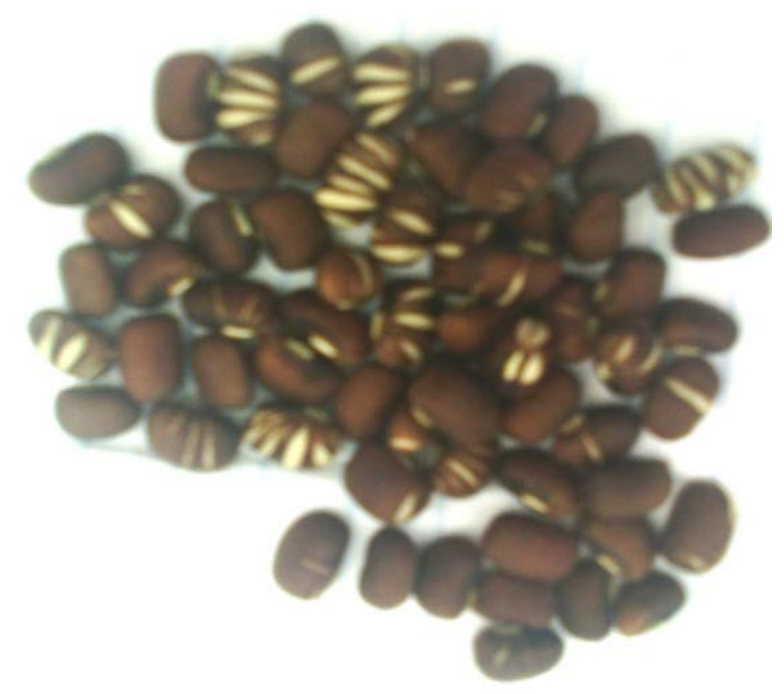

Plate 1: Cowpea TVU 180 seeds used for planting 
experiment were left in each bowls with the cowpea plant. The plant measurements were collected.

Data collection: The plant height and number of leaves were collected weekly. Stem width, number of flowers and number of seeds per pods were also recorded 20 WAP. Total leaf area was determined ${ }^{20}$. The dry matter was taken by harvesting the above ground vegetative parts of three plants per treatment and oven dried at $80^{\circ} \mathrm{C}$ to a constant weight and recorded in grams (g). Estimation of chlorophyll $a / b$ content ${ }^{21}$, total carotenoids, lycopene ${ }^{22}$ were analyzed while the soil nitrogen, phosphorus and potassium content were also determined ${ }^{23}$.

Statistical analysis: All data collected were subjected to descriptive analysis. Difference between the means of the treatments were determined by two way analysis of variance (ANOVA) using SPSS version 20. Significance was set at $5 \%$ probability level $(p<0.05)$. Where significant means are encountered, the data was further subjected to a post hoc test, Duncan's multiple range test. The data were presented in tables and further illustrated by using charts and graphs.

\section{RESULTS}

Plant height: The associated weeds resulted in significant differences among the TVu-180 variety (Fig. 1). No significant difference exist between the treatments and control 1-6 weeks after plant (WAP) until the 8 WAP where weed competitiveness significantly increased the cowpea height in the WE treatment.

Number of leaflet: There was a general decrease in the number of leaflet per plant 1-4 WAP when compared with the control (Fig. 2). Weed competitiveness reduced the number of leaflets 8 WAP in all treatment except in WA, WB and WJ, respectively. The highest number of leaflet was observed in WA and WJ at 10 WAP while no leaflet was recorded in WH.

Yield parameter: Weed competitiveness significantly reduced $(p<0.01)$ the number of pods/plant, seed number/pods, seed weight/pods, length of pods and bean yield, respectively when compare to the control (Table 1). The various weeds treatments suppressed the number of pods in the cowpea except in WA and WI. The highest seed weight per pods was recorded in WA while the length of pods and bean yield of WA and WI were significantly lower than the control.

Below ground parameters: The weed competition increased the root length of TVu-180 in WA, WI, WH, WD and WF treatments over the control (Table 2). However, the highest and lowest root length values were recorded in WA and WC, with an increased number of primary root branches in WD, WH and WA compared to the control. The lowest reduction in the plant dry weight was recorded in WC.

Photosynthetic pigments: The photosynthetic pigments of the TVu-180 variety is presented in Fig. 3(a-d). Weed competitiveness resulted to the highest increase in the

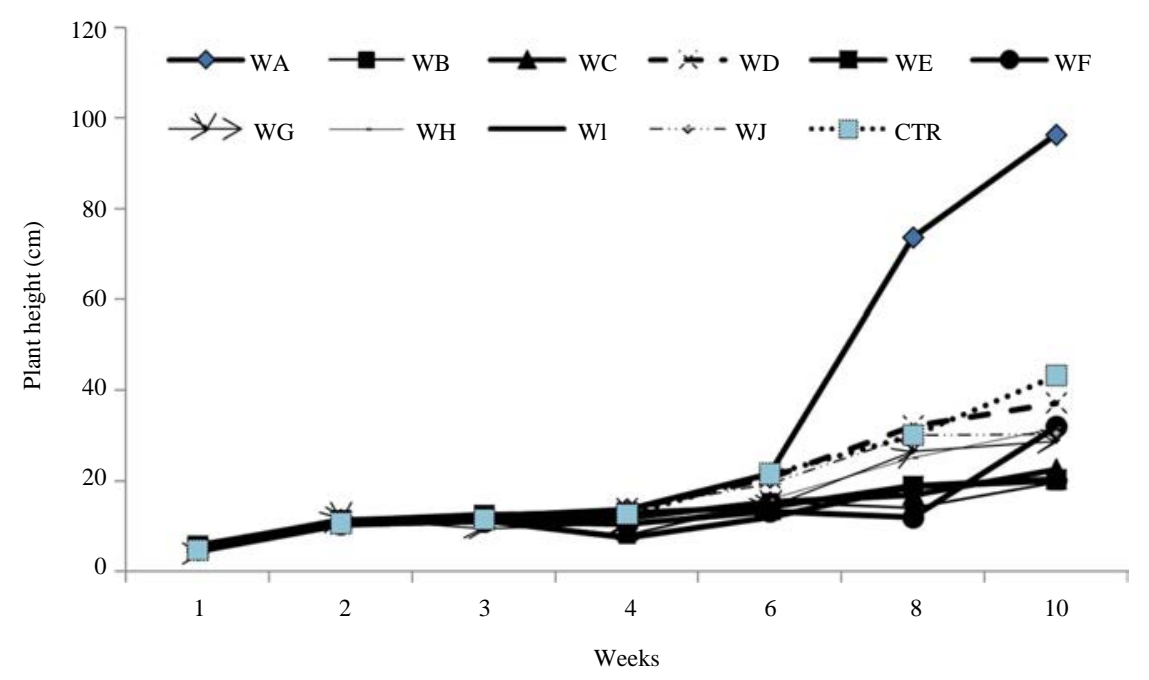

Fig. 1: Progression in plant height 


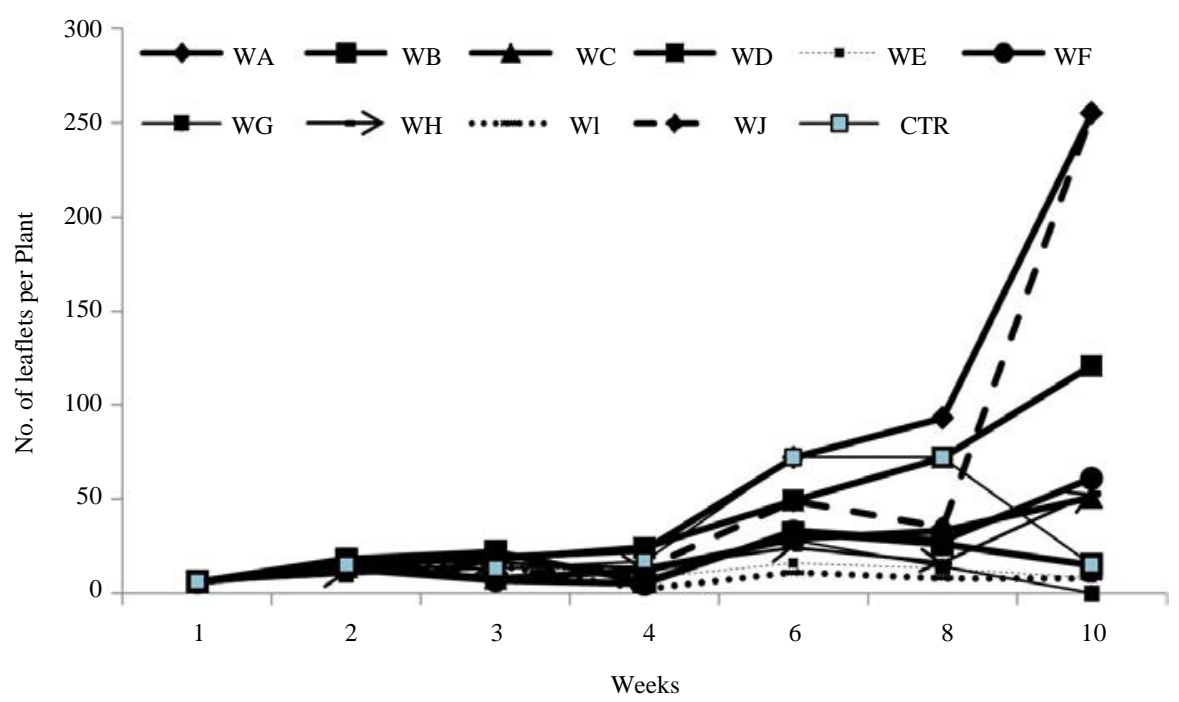

Fig. 2: Progression in number of leaves

Table 1: Effect of treatment on yield parameters

\begin{tabular}{|c|c|c|c|c|c|}
\hline Associated weed & Number of pods/plant & Seed number/pod & Seed wt./pods & Length of pods $(\mathrm{cm})$ & ${ }^{*}$ Bean yield $\left(\right.$ g plant $\left.^{-1}\right)$ \\
\hline WA & $3.57 \pm 0.23^{c}$ & $5.97 \pm 0.15^{\mathrm{b}}$ & $1.22 \pm 0.16^{\mathrm{a}}$ & $7.40 \pm 0.16^{c}$ & $22.53 \pm 1.40^{c}$ \\
\hline WB & $0.00 \pm 0.00^{d}$ & $0.00 \pm 0.00^{c}$ & $0.00 \pm 0.00^{c}$ & $0.00 \pm 0.00^{d}$ & $0.00 \pm 0.00^{d}$ \\
\hline WC & $0.00 \pm 0.00^{d}$ & $0.00 \pm 0.00^{c}$ & $0.00 \pm 0.00^{c}$ & $0.00 \pm 0.00^{d}$ & $0.00 \pm 0.00^{d}$ \\
\hline WD & $0.00 \pm 0.00^{d}$ & $0.00 \pm 0.00^{c}$ & $0.00 \pm 0.00^{c}$ & $0.00 \pm 0.00^{d}$ & $0.00 \pm 0.00^{d}$ \\
\hline VWE & $0.00 \pm 0.00^{d}$ & $0.00 \pm 0.00^{c}$ & $0.00 \pm 0.00^{c}$ & $0.00 \pm 0.00^{d}$ & $0.00 \pm 0.00^{d}$ \\
\hline WF & $0.00 \pm 0.00^{d}$ & $0.00 \pm 0.00^{c}$ & $0.00 \pm 0.00^{c}$ & $0.00 \pm 0.00^{d}$ & $0.00 \pm 0.00^{d}$ \\
\hline WG & $0.00 \pm 0.00^{d}$ & $0.00 \pm 0.00^{c}$ & $0.00 \pm 0.00^{c}$ & $0.00 \pm 0.00^{d}$ & $0.00 \pm 0.00^{d}$ \\
\hline WH & $0.00 \pm 0.00^{d}$ & $0.00 \pm 0.00^{c}$ & $0.00 \pm 0.00^{c}$ & $0.00 \pm 0.00^{d}$ & $0.00 \pm 0.00^{d}$ \\
\hline WI & $5.50 \pm 0.25^{d}$ & $6.23 \pm 0.39^{b}$ & $0.91 \pm 0.01^{b}$ & $7.85 \pm 0.01^{\mathrm{b}}$ & $30.71 \pm 0.81^{b}$ \\
\hline WJ & $0.00 \pm 0.00^{d}$ & $0.00 \pm 0.00$ & $0.00 \pm 0.00^{c}$ & $0.00 \pm 0.00^{d}$ & $0.00 \pm 0.00^{\mathrm{d}}$ \\
\hline CTR & $15.20 \pm 0.15^{\mathrm{a}}$ & $7.33 \pm 0.33^{\mathrm{a}}$ & $0.99 \pm 0.01^{b}$ & $8.33 \pm 0.01^{c}$ & $131.03 \pm 2.25^{\mathrm{a}}$ \\
\hline F-value & 1718.68 & 358.96 & 104.96 & 925.65 & 2226.52 \\
\hline Sig. & $p<0.01$ & $p<0.01$ & $p<0.01$ & $p<0.01$ & $p<0.01$ \\
\hline
\end{tabular}

WA: Chrysopogon aciculatus, WB: Eleusine indica, WC: Cynodon dactylon, WD: Axonopus compressus, WE: Panicumn maximum, WF: Setaria bartata, WG: Sporobolus pyramidalis, WH: Commelina benghalensis, Wl: Paspalum vaginatum, WJ:Combination of all the weeds, CTR:Control,. $\mathrm{p}>0.05$ : Not significant, $\mathrm{p}<0.01$ : Highly significant, Different superscript across the columns shows that means are significant from each other

Table 2: Effects of treatment on below ground parameters

\begin{tabular}{|c|c|c|c|c|c|c|}
\hline $\begin{array}{l}\text { Associated } \\
\text { weed }\end{array}$ & Root length & $\begin{array}{c}\text { Number of primary } \\
\text { root branches }\end{array}$ & $\begin{array}{l}\text { Root dry } \\
\text { weight (g) }\end{array}$ & $\begin{array}{c}\text { Number of root } \\
\text { nodules/plant }\end{array}$ & Nodules weight & $\begin{array}{l}\text { Plant dry } \\
\text { weight (g) }\end{array}$ \\
\hline WA & $42.17 \pm 1.42^{\mathrm{a}}$ & $12.00 \pm 0.58^{c}$ & $1.82 \pm 0.17^{d}$ & $11.67 \pm 0.66^{f}$ & $0.43 \pm 0.04^{\mathrm{d}}$ & $5.17 \pm 0.73^{b}$ \\
\hline WB & $14.23 \pm 0.62^{9}$ & $7.33 \pm 0.33^{d}$ & $0.37 \pm 0.08^{d}$ & $13.33 \pm 0.88^{\mathrm{e}}$ & $0.38 \pm 0.04^{d}$ & $0.84 \pm 0.16^{d}$ \\
\hline WC & $7.23 \pm 0.23^{h}$ & $6.33 \pm 0.67^{d}$ & $0.54 \pm 0.26^{d}$ & $12.00 \pm 1.00^{f}$ & $0.37 \pm 0.03^{d}$ & $1.40 \pm 0.31^{c}$ \\
\hline WD & $30.43 \pm 0.87^{d}$ & $16.33 \pm 2.18^{a}$ & $1.65 \pm 0.38^{c}$ & $19.00 \pm 1.52^{b}$ & $0.61 \pm 0.05^{\mathrm{a}}$ & $5.34 \pm 1.46^{\mathrm{a}}$ \\
\hline WE & $10.13 \pm 0.47^{\mathrm{h}}$ & $7.33 \pm 1.20^{\mathrm{d}}$ & $0.45 \pm 0.26^{d}$ & $8.33 \pm 1.45^{f}$ & $0.33 \pm 0.04^{b}$ & $1.19 \pm 0.43^{b}$ \\
\hline WF & $27.73 \pm 2.60^{d}$ & $10.67 \pm 1.76^{d}$ & $0.61 \pm 0.21^{d}$ & $18.33 \pm 2.90^{c}$ & $0.51 \pm 0.05^{c}$ & $1.95 \pm 0.62^{b}$ \\
\hline WG & $10.67 \pm 1.86^{\mathrm{h}}$ & $8.00 \pm 2.00^{d}$ & $0.18 \pm 0.06^{d}$ & $7.00 \pm 1.52^{f}$ & $0.29 \pm 0.06^{d}$ & $1.47 \pm 0.78^{d}$ \\
\hline WH & $33.27 \pm 0.89^{c}$ & $12.00 \pm 1.15^{b}$ & $0.87 \pm 0.12^{\mathrm{d}}$ & $12.67 \pm 2.02^{\mathrm{e}}$ & $0.44 \pm 0.03^{c}$ & $3.25 \pm 0.38^{c}$ \\
\hline Wl & $35.07 \pm 1.73^{b}$ & $15.33 \pm 2.33^{b}$ & $2.87 \pm 0.24^{b}$ & $10.67 \pm 0.88^{f}$ & $0.44 \pm 0.03^{c}$ & $5.11 \pm 0.68^{b}$ \\
\hline WJ & $16.97 \pm 1.02^{f}$ & $10.67 \pm 2.19^{d}$ & $0.91 \pm 0.09^{d}$ & $15.00 \pm 1.73^{d}$ & $0.38 \pm 0.04^{d}$ & $1.91 \pm 0.25^{d}$ \\
\hline $\mathrm{CT}$ & $23.17 \pm 1.92^{\mathrm{e}}$ & $9.00 \pm 1.53^{\mathrm{d}}$ & $3.54 \pm 0.31^{\mathrm{a}}$ & $21.67 \pm 2.40^{\mathrm{a}}$ & $0.60 \pm 0.04^{\mathrm{a}}$ & $6.37 \pm 0.23^{\mathrm{a}}$ \\
\hline F-value & 68.05 & 4.22 & 24.15 & 7.27 & 6.19 & 9.63 \\
\hline Significant & $\mathrm{p}<0.01$ & $p<0.01$ & $p<0.01$ & $\mathrm{p}<0.01$ & $p<0.01$ & $\mathrm{p}<0.01$ \\
\hline
\end{tabular}

WA: Chrysopogon aciculatus, WB: Eleusine indica, WC: Cynodon dactylon, WD: Axonopus compressus, WE: Panicumn maximum, WF: Setaria bartata, WG: Sporobolus pyramidalis, WH: Commelina benghalensis, WI:Paspalum vaginatum, WJ:Combination of all the weeds, CTR:Control, $\mathrm{p}>0.05$ : Not significant, $\mathrm{p}<0.01$ : Highly significant Different superscript across the columns shows that means are significant from each other 

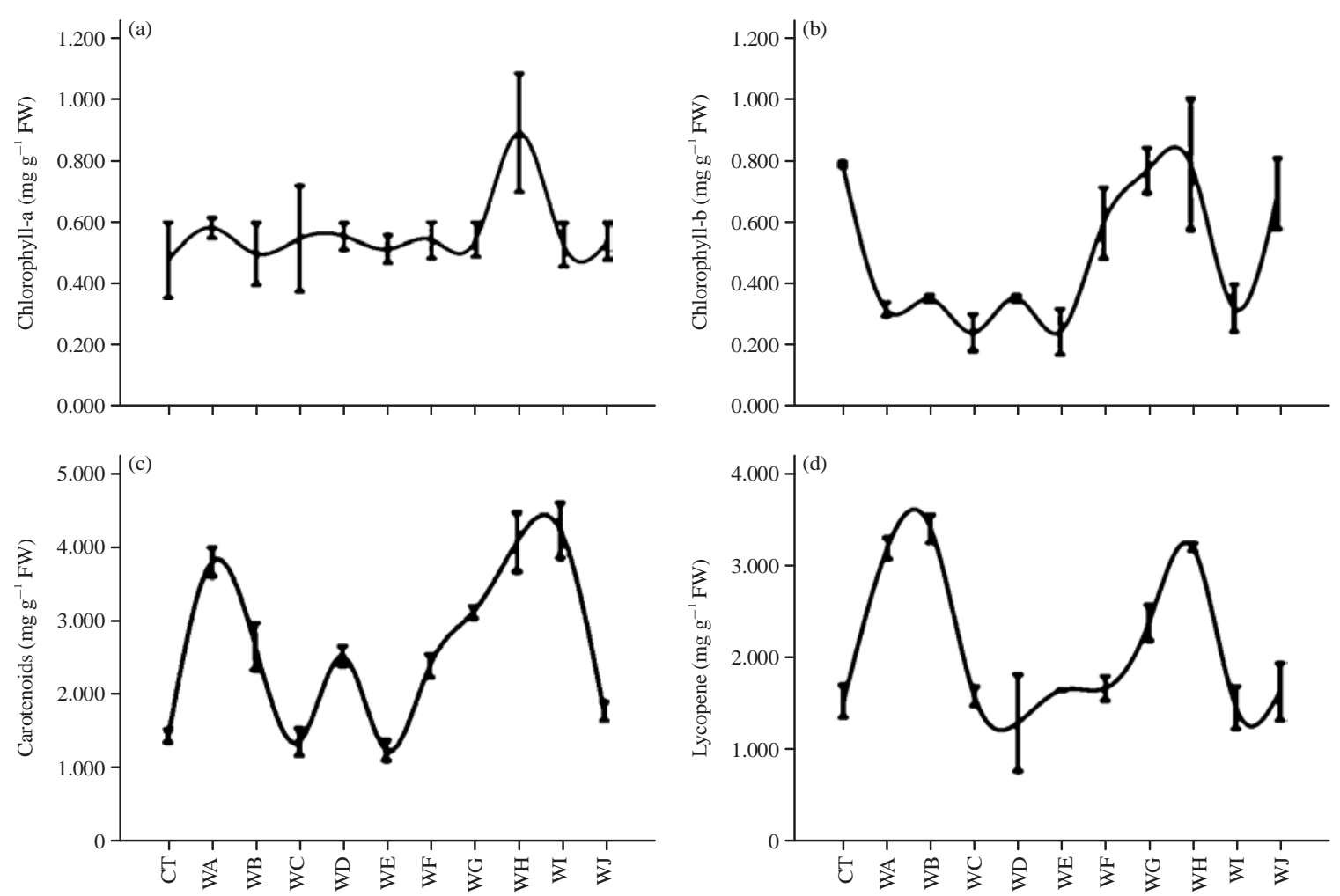

Fig.3(a-d): Effect of treatment on photosynthetic pigments, (a) Chlorophyll-a content, (b) Chlorophyll-b content, (c) Carotenoids and (d) Lycopene

WA: Chrysopogon aciculatus, WB: Eleusine indica, WC: Cynodon dactylon, WD: Axonopus compressus, WE: Panicumn maximum, WF: Setaria bartata, WG: Sporobolus pyramidalis, WH: Commelina benghalensis, WI: Paspalum vaginatum, WJ: Combination of all the weeds, CT: Control, $\mathrm{p}<0.05$ : Significant, $\mathrm{p}<0.01$ : Highly significant

chlorophyll-a/b content in WH (Fig. 3a and b). The WC and WE recorded the lowest carotenoid levels compared (Fig. 3c) while WB had the highest lycopene content over the control (Fig. 3d).

Soil total NPK: The associated weed resulted in significant reduction in the soil total N\% of the treatments except in WD and WI, respectively when compared to the control (Fig. 4a). The lowest soil total $P$ content was recorded in the WC (Fig. 4b). Weed competitiveness resulted in a highly significant reduction in soil total $\mathrm{K}$ of the WD treatment compared to the control (Fig. 4c).

Correlation: The correlation between the tested plant parameters is presented (Table 3). There was a strong positive relationship between chlorophyll-a content and lycopene with a high negative relationship with $\mathrm{N}$. The chlorophyll-b content showed positive significant relationship with $\mathrm{K}$. The positive relationship observed between the bean yield and soil N, P, K may have contributed to the yield recorded in the control, WA and WI, respectively.

\section{DISCUSSION}

There is little to no information on studies that have focused on the competitiveness of a single cowpea variety exposed to different prominent weeds present in an ultisol, especially in Benin city, Nigeria. Competition between weeds and crops is expressed by altered growth and development of both species. Results in the study have shown that the different associated weed either singly or holistically have significant effects on the growth, development and productivity of the cowpea plant. This effects differs among the selected associated weeds. The increased plant height recorded in the TVu-180 grown in the Panicumn maximum (WE) soil when compared to the suppressed growth recorded in the other weed treatments maybe due to the genetic buildup inherent within the plant cells. It was reported that weeds do not cause harm to crops equally all through the growing period ${ }^{24}$. Although the number of leaflet recorded in the associated weed were significantly higher than the control, no leaf was recorded in the WH treatment which can be directly associated with the degree of weed infestation 

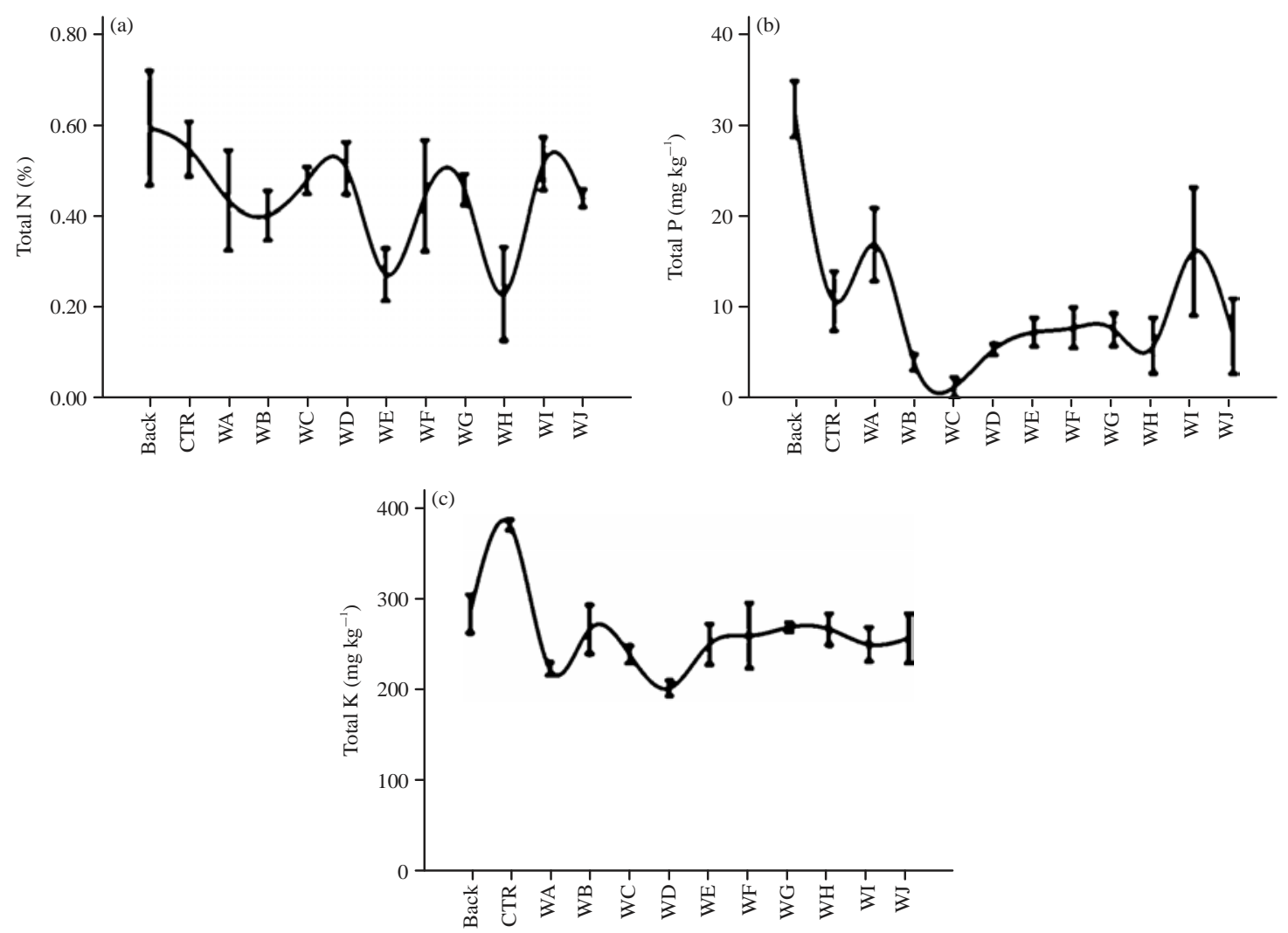

Fig. 4(a-c): Soil levels the major micro-nutrient, (a) Total nitrogen (\%), (b) Total phosphorus and (c) Total potassium

WA: Chrysopogon aciculatus, WB: Eleusine indica, WC: Cynodon dactylon, WD: Axonopus compressus, WE: Panicumn maximum, WF: Setaria bartata, WG: Sporobolus pyramidalis, WH: Commelina benghalensis, WI: Paspalum vaginatum, WJ: Combination of all the weeds, CT: Control, $\mathrm{p}>0.05$ : Not significant, $p<0.01$ : Highly significant

\begin{tabular}{|c|c|c|c|c|c|c|c|c|c|c|c|c|c|}
\hline Variables & & ChloroA & ChloroB & Carotenoid & Lycopene & $\begin{array}{l}\text { Leaf } \\
\text { number }\end{array}$ & $\begin{array}{l}\text { Leaf } \\
\text { area }\end{array}$ & $\begin{array}{l}\text { Nodule } \\
\text { number }\end{array}$ & $\begin{array}{l}\text { Nodule } \\
\text { weight }\end{array}$ & $\begin{array}{l}\text { Bean } \\
\text { yield }\end{array}$ & $\mathrm{N}$ & $P$ & $\mathrm{~K}$ \\
\hline \multirow{2}{*}{ ChloroA } & Pearson Corr. (r) & 1 & 0.3214 & -0.018 & $0.4012^{*}$ & -0.1370 & -0.1150 & -0.0240 & -0.0060 & -0.2320 & $-0.5710^{* *}$ & -0.0090 & -0.144 \\
\hline & Significant & & 0.0682 & 0.921 & 0.0207 & 0.4468 & 0.5229 & 0.8953 & 0.9724 & 0.1935 & 0.0005 & 0.9601 & 0.425 \\
\hline \multirow[t]{2}{*}{ ChloroB } & Pearson Corr. (r) & & 1 & -0.135 & 0.0788 & 0.1756 & 0.1820 & 0.2733 & 0.0938 & 0.3048 & -0.0340 & 0.0438 & $0.508^{* *}$ \\
\hline & Significant & & & 0.455 & 0.6628 & 0.3284 & 0.3107 & 0.1238 & 0.6036 & 0.0845 & 0.8516 & 0.8089 & 0.003 \\
\hline \multirow[t]{2}{*}{ Carotenoid } & Pearson Corr. (r) & & & 1 & -0.0080 & -0.0740 & -0.2190 & -0.1020 & -0.0680 & 0.0274 & 0.1341 & 0.2995 & -0.025 \\
\hline & Significant & & & & 0.9651 & 0.6844 & 0.2212 & 0.5716 & 0.7067 & 0.8797 & 0.4570 & 0.0905 & 0.890 \\
\hline \multirow[t]{2}{*}{ Lycopene } & Pearson Corr. (r) & & & & 1 & -0.1030 & 0.21050 & -0.2770 & -0.2870 & -0.2130 & $-0.444^{* *}$ & 0.0306 & -0.039 \\
\hline & Significant & & & & & 0.5671 & 0.23970 & 0.1182 & 0.1056 & 0.2337 & 0.0096 & 0.8656 & 0.828 \\
\hline \multirow[t]{2}{*}{ Leaf number } & Pearson Corr. (r) & & & & & 1 & $0.7219^{* *}$ & $0.4577^{* *}$ & $0.4401^{* *}$ & $0.6362^{* *}$ & 0.3327 & $0.4145^{*}$ & 0.262 \\
\hline & Significant & & & & & & 0.000001 & 0.0074 & 0.0104 & 0.00007 & 0.0585 & 0.0165 & 0.140 \\
\hline \multirow[t]{2}{*}{ Leaf area } & Pearson Corr. (r) & & & & & & 1 & $0.3438^{*}$ & 0.1933 & $0.3983^{*}$ & 0.0521 & 0.2024 & 0.239 \\
\hline & Significant & & & & & & & 0.0501 & 0.2810 & 0.0217 & 0.7732 & 0.2586 & 0.180 \\
\hline \multirow[t]{2}{*}{ Nodule number } & Pearson Corr. (r) & & & & & & & 1 & $0.5478^{* *}$ & $0.4557^{* *}$ & 0.2899 & -0.0350 & 0.295 \\
\hline & Significant & & & & & & & & 0.0010 & 0.0077 & 0.1018 & 0.8471 & 0.095 \\
\hline \multirow[t]{2}{*}{ Nodule Wt } & Pearson Corr. (r) & & & & & & & & 1 & $0.4593^{* *}$ & 0.3169 & 0.1698 & 0.172 \\
\hline & Significant & & & & & & & & & 0.0072 & 0.0724 & 0.3447 & 0.337 \\
\hline \multirow[t]{2}{*}{ Bean yield } & Pearson Corr. (r) & & & & & & & & & 1 & $0.4082^{* *}$ & $0.3659^{* *}$ & $0.786^{* *}$ \\
\hline & Significant & & & & & & & & & & 0.0184 & 0.0362 & 0.0001 \\
\hline \multirow[t]{2}{*}{ N } & Pearson Corr. (r) & & & & & & & & & & 1 & 0.2052 & 0.202 \\
\hline & Significant & & & & & & & & & & & 0.252 & 0.259 \\
\hline \multirow[t]{2}{*}{$P$} & Pearson Corr. (r) & & & & & & & & & & & 1 & 0.035 \\
\hline & Significant & & & & & & & & & & & & 0.845 \\
\hline \multirow[t]{2}{*}{ K } & Pearson Corr. (r) & & & & & & & & & & & & 1 \\
\hline & Significant & & & & & & & & & & & & \\
\hline
\end{tabular}

by Commelina benghalensis. Lemos et al.25 once reported that Commelina benghalensis, Bidens pilosa and Ipomoea triloba reduced the shoot dry matter of maize. However, the highest number of leaflet observed in WA (Chrysopogon 
aciculatus) and WJ (combination of all the weeds) compared to the control was a survival strategy employed by the cowpea to shade sunlight from penetrating down to the weeds. There was variability in the root length and No. of primary root branches of the cowpea to the various weeds treatments. The weed competition significantly reduced the root dry weight, No. of root nodules, nodules weight and plant dry weight of the TVu-180 compared to the control. The inability of the cowpea plants in some of the weedy pots to produce more leaves and probably cover more areas could be attributed to its adaptive mechanism to the competitive growth condition. Due to the fact that weeds in greater densities possess great challenges to the growth of cowpea and resulted in yield reduction ${ }^{26}$.

The potentials of the cowpea in competition with the various weeds can further be explained in the cowpea yield productivity recorded 20 WAP. The significant reduction in the yield parameters showed that the presence of weed had deleterious effects on the yield productivity of the cowpea plant which was further observed in the bean yield of the plant. This can also be attributed to the inability of the cowpea plant to compete favourably in the presence of the various species of weed. This observation is similar to the report of Tripathi and Singh ${ }^{27}$, who pointed out that cowpea usually face critical growth challenges in the presences of weeds. An indication that the competitive effect of the weeds affected the root length from normal. Similar effect was observed in the number of primary root branches. Some treatments such as WD, WH and WA develop more primary root to compete for nutrient adequately. Although the TVu-180 grown in the WA (Chrysopogon aciculatus) and WI (Paspalum vaginatum) produced yield, this was significantly lower than the control. This poor yield and yield parameters observed in this study further gives tendencies to the fact that weed infestation reduces crop yield and agrees with reports that in Nigeria, the presence of weeds causes $53-60 \%$ yield loss in legumes ${ }^{28}$. Similarly, the poor grain yield observed in cowpea was substantially increased when the weeds was controlled $^{29}$.

The positive relationships observed from the data indicates that an increase in lycopene and soil $\mathrm{K}$ resulted in an increase in chlorophyll-a and chlorophyll-b content. The positive significant relationship observed in leaf number/area, nodule number/weight and bean yield showed the relevant of the leaf as the major primary parameter for crop productivity.

\section{CONCLUSION}

Cowpea has a great economic potential as both domestic and commercial crop. The extent of yield losses cause by weeds alone in cowpea production varies with respective weeds. This may also be due to the increased carotenoid and lycopene levels which serves as accessory pigments to chlorophyll. A timely weed removal at the critical period few day after cowpea emergence would mitigate its effect in preventing unacceptable yield lost.

\section{SIGNIFICANCE STATEMENT}

This study discovers that the cowpea TVu- 180 variety is one of the most promising cultivar for farmers in improving yield productivity and food security especially in farm infested with Chrysopogon aciculatus and Paspalum vaginatum weeds. Molecular and genetic studies should further be carried out before a major decision could be determined about its large scale cultivation in an ultisol.

\section{ACKNOWLEDGMENT}

The authors are grateful to the Environmental Biotechnology and Sustain ability Research Group and the Department of Plant Biology and Biotechnology both in the University of Benin, Benin city, Nigeria.

\section{REFERENCES}

1. Singh, B.B., 1993. Cowpea breeding archival report (1988-1992) of grain legume improvement program. International Institute of Tropical Agriculture (IITA), Ibadan, Nigeria, pp: 10-53.

2. Paudulosi, S. and N.O. Ng, 2006. Origin Taxonomy and Morphocophy of Vigna unguiculata (L.) Walp. In: Advances in Cowpea Research, Singh, B.B., D.R.M. Raj, K.E. Dashiell and I.E.N. Jaikai (Eds.). International Institute of Tropical Agriculture (IITA), Ibadan, Nigeria, pp: 215-224.

3. Ayodele, J.T. and I.R. Yalwa, 2004. Amino acid composition of Vigna dekindtiana. Biol. Environ. Sci. J. Trop., 1: 120-126.

4. Steel, W.M., 1996. Cowpea. In: Evolution of Crop Plants, Simmond (Ed.)., Longman, Essex, England, pp: 183-185.

5. FAO., 2014. FAOSTAT: Statistical Database. Food and Agriculture Organization of the United Nations, Rome, Italy.

6. Osipitan, O.A., 2017. Weed interference and control in cowpea production: A review. J. Agric. Sci., 9: 11-20.

7. Adigun, J., A.O. Osipitan, S.T. Lagoke, R.O. Adeyemi and S.O. Afolami, 2014. Growth and yield performance of cowpea (Vigna unguiculata (L.) Walp) as influenced by row-spacing and period of weed interference in South-West Nigeria. J. Agric. Sci., 6: 188-198. 
8. Kanteh, S.M., J.E. Norman and J. Sherman-Kamara, 2014. Effect of plant density and weeding regime on population and severity of aphids (Aphis craccivoraKoch) and foliage beetles (Ootheca mutabilis Sahl) on cowpea in sierra leone. Int. J. Agric. For., 4: 24-33.

9. Adusei, G., T. Gaiser, O. Boukar and C. Fatokun, 2016. Growth and yield responses of cowpea genotypes to soluble and rock $P$ fertilizers on acid, highly weathered soil from humid tropical West Africa. Int. Biol. Chem. Sci., 10: 1493-1507.

10. Osipitan, O.A., J.A. Adigun and R.O. Kolawole, 2016. Row spacing determines critical period of weed control in crop: Cowpea (Vigna unguiculata) as a case study. Azarian J. Agric., 3: $90-96$.

11. Thio, I.G., E.P. Zida, M. Sawadogo and P. Sereme, 2016. Current status of Colletotrichum capsici strains, causal agents of brown blotch disease of cowpea in Burkina Faso. Afr. J. Biotechnol., 15: 96-104.

12. Abudulai, M., F. Kusi, S.S. Seini, A. Seidu, J.A. Nboyine and A. Larbi, 2017. Effects of planting date, cultivar and insecticide spray application for the management of insect pests of cowpea in northern Ghana. Crop Prot., 100: 168-176.

13. Ohanmu, E.O. and B. Ikhajiagbe, 2018. Enzymatic and non-enzymatic response of Sphenostylis stenocarpa to cadmium stress. Asian J. Applied Sci., 11: 125-134.

14. Ajeigde, H.A., B.B. Singh and T.O. Osenj, 2005. Cowpea-cereal intercrop productivity in the Sudan savanna zone of Nigeria as affected by planting pattern, crop variety and pest management. Afr. Crop Sci. J., 13: 269-279.

15. Gupta, K.C., A.K. Gupta and S. Rani, 2016. Weed management in cowpea [Vigna unguiculata (L.) Wasp.] under rainfed conditions. Int. J. Agric. Sci., 12: 238-240.

16. Ugbe, L.A., N.U. Ndaeyo and J.F. Enyong, 2016. Efficacy of selected herbicides on weed control, cowpea (Vigna uniguiculata L. Walp) performance and economic returns in Akamkpa, Southeastern Nigeria. Int. J. Res. Agric. For., 19: 19-27.

17. Prabhu, G., R. Srinivasan, S.R. Kantwa, D.R. Palsaniya and M. Chaudhary, 2015. Weed seed bank studies in the field of fodder cowpea [Vigna unguiculata (L.)]. Int. J. Applied Pure Sci. Agric., 1: 83-87.
18. Mekonnen, G., J.J. Sharma, T. Tana and L. Nigatu, 2015. Effect of integrated weed management practices on weeds infestation, yield components and yield of Cowpea [Vigna unguiculata (L.) Walp.]. Eastern Wollo, Northern Ethiopia. Am. J. Exp. Agric., 7: 326-346.

19. Singh, M.C. and C.V. Sairam, 2016. Effect of spacing and intercropping with cowpea on weed growth in banana. Int. J. Environ. Sci. Technol., 5: 558-563.

20. Okonokhua, B.O., B. Ikhajiagbe, G.O. Anoliefo and T.O. Emede, 2007. The effects of spent engine oil on soil properties and growth of maize (Zea mays L.). J. Applied Sci. Environ. Manage., 11: 147-152.

21. Arnon, D.I., 1949. Copper enzymes in isolated chloroplasts. Polyphenoloxidase in Beta vulgaris. Plant Physiol., 24: 1-15.

22. Ruch, R.J., S.J. Cheng and J.E. Klaunig, 1989. Prevention of cytotoxicity and inhibition of intercellular communication by antioxidant catechins isolated from Chinese green tea. Carcinogenesis, 10: 1003-1008.

23. AOAC., 2005. Official method of analysis (Codex general method 972.25). Association of Official Analytical Chemist, Arlington, VA., USA.

24. Das, T.K., 2008. Weed Science: Basics and Applications. Jain Brothers, New Delhi, ISBN: 8183600964, pp: 901-902.

25. Lemos, J.P., J.C.C. Galvão, A.A. da Silva, A. Fontanetti and L.M.C. Lemos, 2012. [Effect of clearings of bidens pilosa and commelina benghalensis species on morphological characteristics of corn]. Rev. Bras. Agropecuaria Sustentavel, 2: $32-40$.

26. Nangju, D. and T. Wanki, 1980. Effects of density, plant type and season on growth and yield of cowpea. J. Am. Soc. Hortic. Sci., 104: 446-470.

27. Tripathi, S.S. and G. Singh, 2001. Critical period of weed competition in summer cowpea [Vigna unguiculata (L.) Walp.]. Indian J. Weed Sci., 33: 67-68.

28. Madukwe, D.K., H.C. Ogbuehi and M.O. Onuh, 2012. Effects of weed control methods on the growth and yield of cowpea (Vigna unguiculata (L.) Walp.) under rain-fed conditions of Owerri. Am.-Eurasian J. Agric. Environ. Sci., 11: 1426-1430.

29. Onuh, M.O., E.N. Ukonu, A.E. Ibe, D.K. Madukwe and D.E. Iheaturu, 2015. Performance of cowpea (Vigna unguiculata $(\mathrm{L})$ Walp) as influence by different weed control methods. J. Biol. Agric. Healthcare, 5: 178-185. 